\title{
A global overview on the diet of the dice snake (Natrix tessellata) from a geographical perspective: foraging in atypical habitats and feeding spectrum widening helps colonisation and survival under suboptimal conditions for a piscivorous snake
}

András Weiperth', Tibor Gaebele ${ }^{2}$, Imre Potyó ${ }^{1}$ and Miklós Puky ${ }^{1 *}$

\begin{abstract}
Background: The dice snake (Natrix tessellata Laurenti, 1768) is generally considered to be a fully or partially piscivorous freshwater snake species. The aim of the study was to make the first global overview on the taxonomy and geographical distribution of the species based on own observations, available databases and the special literature.

Results: Besides freshwaters, $N$. tessellata turned out to hunt also in marine and terrestrial habitats predating on at least 29 and 15 species, respectively. On the basis of our data and the literature altogether, 113 prey taxa, mostly fish, were listed but $20 \%$ of them were invertebrates, amphibians, reptiles and mammals. The importance of non-fish species in the diet was especially pronounced in deserts, high mountains and in dry Mediterranean areas. In spite of the wide feeding spectrum, only fish and amphibians were found to be predominant food items over the whole species' range. Fish dominated the catch of the dice snake in most quantitative studies, except one survey in Turkey, where the ratio of non-fish prey items was over $50 \%$.

Conclusions: The global analysis of the diet of the dice snake revealed a feeding spectrum characteristically changing over the broad distribution area including non-fish prey as well as taxa from marine and terrestrial habitats. The analysis of the feeding spectrum separated four large geographical units with further distinctions in Central and Eastern Europe. Such diversity helps explain why this species was able to colonise a large and diverse Eurasian range.
\end{abstract}

Keywords: Natrix tessellata; Reptilia; Diet; Feeding spectrum

\section{Background}

The dice snake (Natrix tessellata Laurenti, 1768) is a Eurasian snake species ranging from Germany and Switzerland to China, Pakistan and Egypt (Gasc et al. 1997; Ibrahim 2012; Mebert et al. 2013) and is well adapted to the aquatic environment (Lahav and Dmi'el

\footnotetext{
*Correspondence: puky.miklos@okologia.mta.hu

'MTA Centre for Ecological Research, Danube Research Institute, Karolina út 29 , Budapest 1113, Hungary

Full list of author information is available at the end of the article
}

1996; Nekrasova et al. 2013). It occurs in aquatic or marshy habitats, including brackish water (Gruschwitz et al. 1999; Khonjakina 1969; Tuniyev et al. 2011) occasionally even inhabiting cities such as Rome and Prague (Velenský et al. 2011; Vignoli et al. 2009). The distribution area of the dice snake is partly overlapped with two other aquatic Natrix species. The grass snake (Natrix natrix) lives in Eurasian habitats, often inhabiting similar areas with the dice snake (Gasc et al. 1997) while the viperine snake (Natrix maura) has sympatric populations in Switzerland 
and Italy with the dice snake (Metzger et al. 2011; Scali 2011). It is listed in Annex II of the Bern Convention (1999) and it also appears in Annex IV of the Habitat Directive of the European Union (1992) but due to its wide distribution and presumably large population size, it is categorised as least concern by IUCN (2012). However, it is considered to be threatened in a number of western and central European states, with low genetic variation in some populations (Gautschi et al. 2002; Guicking et al. 2004) and its world population was also assessed as declining (IUCN 2012). As such, conservation measures should still be undertaken for this species as habitat destruction, pollution, road traffic, collection and persecution are listed as possible threats.

The dice snake has a large distribution and it occurs in different habitats, which would imply the species can adapt well to local conditions presumably by adopting a wide feeding spectrum. However, it is generally considered to be a diurnal piscivorous snake (Gasc et al. 1997) despite information that shows the species also eats non-fish prey items such as amphibians and reptiles (see e.g. Beshkov and Dushkov 1981). A number of publications contain information on the food of the dice snake, with several focusing on local areas (e.g. Luiselli et al. 2007 on Central Italy), but no global overview of the species' dietary preferences has been published.

The aim of this paper is to review the feeding spectrum of the dice snake over its global distribution by comparing the species' prey items in different countries and offer reasons for potential differences in prey item preference based on geography and habitat conditions.

\section{Methods}

Information was gathered from literature sources and personal observations on the diet of the dice snake from its whole range, i.e. from Switzerland in the west to Pakistan and China in the east, and from Germany in the north to Iran in the south. Information from papers only mentioning large, collective groups such as 'insects', 'fish' or 'frogs' as food items without giving species (or genus) level information is discussed in the article (e.g. Brecko et al. 2011) but was not included in the database, even if their addition would have added new items to the list such as mice (Wang et al. 1987) or shrews (Radovanović 1951). No time limit was applied; reports available from the first half of the twentieth century were also used. Besides published records and our observations, citizen science data were also collected by approaching internet databases for photographic evidence of dice snake predation on a given taxa (e.g. http://www.varangy.hu/, http://www.wuerfelnatter. $\mathrm{de} /$ ). The distribution of different prey classes among different habitats was calculated and information on their frequency in the diet of the dice snake was also summarised. Species with no indication of frequency in the diet were listed under 'no quantitative data', whereas the following frequencies were listed when quantitative data was available: under $5 \%=$ rare; $5 \%$ to $20 \%=$ frequent; and $>20 \%=$ common. Studies including quantitative data were also used for comparison after the relative abundance of prey taxa were calculated. Association analysis with the presence-absence data of the prey taxa of the dice snake were used in non-metric cluster analysis (Goodall 1953; Podani 1997, 2001; Williams and Lambert 1960) to elucidate geographical differences among 18 countries, where appropriate information could be collected. Statistical analysis was made using SYN-TAX 2000 (Podani 2001). Results were plotted by MS Office 2010 and SYN-TAX 2000 (Podani 2001).

\section{Results}

\section{Species composition of prey taxa}

Altogether, 113 animal taxa have been listed as prey for the dice snake belonging to three phyla: Mollusca, Arthropoda and Vertebrata. The ratio of classes among the taxa is 3\% Gastropoda, 2\% Insecta, $80 \%$ Pisces, $10 \%$ Amphibia, 3\% Reptilia and 2\% Mammalia. The complete list of prey species together with the indication of their frequency in the diet, country and habitat recorded is in Additional file 1 .

Figure 1 contains the number of species from the different classes in different habitats and their frequency distribution. It shows that in marine habitats, only fish were predated; in freshwater and terrestrial habitats, the most frequently eaten prey items were fishes and amphibians, respectively. The quantitative data shows that fish and amphibians overall were the most frequently eaten prey items, with invertebrates, reptiles and mammals eaten only rarely.

\section{Abundance of prey taxa in the diet of the dice snake}

Detailed quantitative data on the diet of the dice snake were found in eight articles (Acipinar et al. 2006; Bakiev et al. 2011; Filippi et al. 1996; Göçmen et al. 2011; Hutinec and Mebert 2011; Luiselli et al. 2007; Sloboda et al. 2010; Zimmerman and Fachbach 1996) including 2,375 prey items from the investigation of more than 2,730 snakes. The relative abundance of the different fauna groups at six European and two Asian sites is summarised in Figure 2, which shows a relatively uniform pattern, fishes comprised the highest abundance of prey items in seven out of the eight studies (Acipinar et al. 2006; Bakiev et al. 2011; Filippi et al. 1996; Göçmen et al. 2011; Hutinec and Mebert 2011; Luiselli et al. 2007; Sloboda et al. 2010; Zimmerman and Fachbach 1996). In four surveys (Austria, Croatia, Northern Turkey, Romania), they were the only food items described, while in Italy, amphibians were also eaten in both cases. 


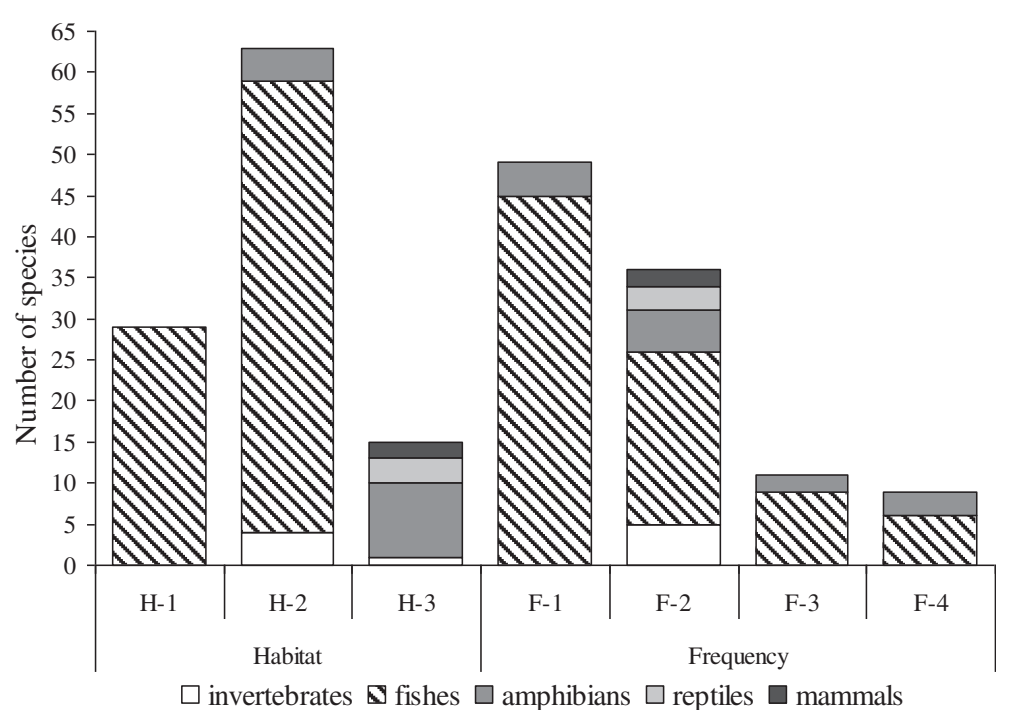

Figure 1 Number and frequency of prey species in the diet of Natrix tessellata in different habitats. Invertebrates were united into one group due to their low number and similar distribution. Code of categories: $\mathrm{H}-1$ : marine, $\mathrm{H}-2$ : freshwater, $\mathrm{H}-3$ : terrestrial, F-1: no quantitative data, F-2: rare, F-3: frequent, F-5: common.

Unlike these studies, fishes did not have an absolute dominance among the prey items in Central Turkey (Acipinar et al. 2006); dice snakes also consumed invertebrates (Bakiev et al. 2011; Göçmen et al. 2011), amphibians (Bakiev et al. 2011; Hutinec and Mebert 2011) and, to a moderate extent, reptiles (Bakiev et al. 2011; Filippi et al. 1996; Luiselli et al. 2007) and mammals (Göçmen et al. 2011).

\section{Geographical differences in the feeding spectrum of the dice snake}

Species (and, in some cases, genus) level data on the feeding spectrum of the dice snake was collected from 18 countries. Their similarity can be seen in Figure 3 . The highest number of prey species eaten was found in studies conducted in Russia, Bulgaria and Switzerland, the lowest in Iran, Syria and Slovenia. Fish were

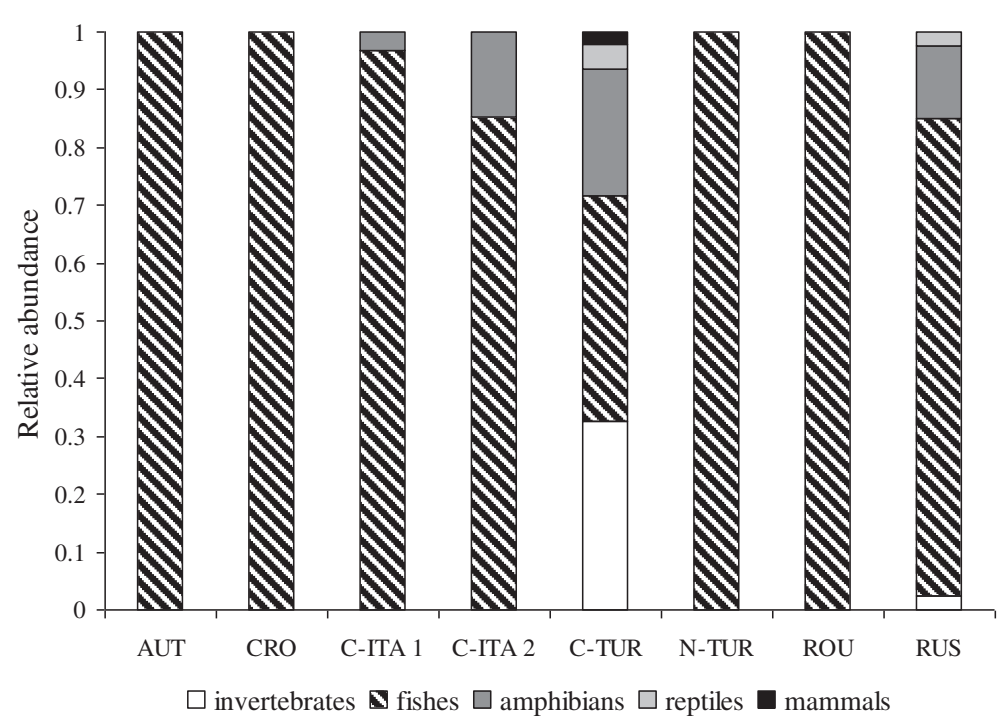

Figure 2 Relative abundance of prey items in the diet of Natrix tessellata in seven Eurasian studies. Invertebrates were united into one group due to their low number and similar distribution. Country codes: AUT: Austria, CRO: Croatia, C-ITA 1: Central Italy, C-ITA 2: Northern Italy, C-TUR: Central Turkey, N TUR: Northern Turkey, ROU: Romania, RUS: Russia. 
recorded in the diet of the dice snake in all countries and they comprised the highest number of species eaten in each of them. In spite of the high ratio of fishes among prey items investigated, in nearly $75 \%$ of the countries (Italy, Turkey, Switzerland, Slovenia, Czech Republic, Poland, Russia, Romania, Bulgaria, Georgia, Azerbaijan, Syria, Jordan), other prey groups were also found, amphibians in all these cases, invertebrates, reptiles and mammals in two or three countries. Invertebrates and mammals were only recorded in the diet of the dice snakes in Turkey and Russia and reptiles in those of Italy, Turkey and Russia. These results show the widest dietary niche of the dice snake is occurring in Turkey and Russia, with all five prey groups shown to be eaten in previous studies.

The analysis of the results revealed zoogeographical differences in the feeding spectrum of the dice snake (Figure 4). In the Middle East, the number of species eaten was relatively low (under eight species in any country) with only fish and amphibians eaten. The same taxa characterise countries in the Ponto-Caspian group but different species are fed on and the number of species was also higher. The remaining two groups (Central and Eastern European, Mediterranean) are characterised by a wide feeding spectrum, characteristic differences among the countries and further division in the Central and Eastern European group e.g. according to altitude.

\section{Discussion}

Data from 18 countries proved that the dice snake feeds on at least 113 prey taxa from six classes. Fish were the most important prey items; the importance of non-fish species in the diet was pronounced in deserts, high mountains and in dry Mediterranean areas. In spite of the wide feeding spectrum, only fish and amphibians were found to be predominant food items over the whole species' range.

\section{Species composition of prey taxa}

Due to its excellent swimming and diving abilities and fidelity to freshwater habitats, the dice snake is generally considered to be a piscivorous fish species (Gasc et al. 1997, Kreiner 2007). However, the global feeding spectrum of the dice snake is surprisingly wide; it also includes a reasonable number of marine and terrestrial species (Figure 1), both fast- and slow-moving animals. For example, reptiles, especially lizards, have been found in the diet of the dice snake for more than 60 years (Göçmen et al. 2011), and slow aquatic and terrestrial invertebrates, snails and insects were also repeatedly reported (Additional file 1) (Bakiev et al. 2011; Göçmen et al. 2011; Wang et al. 1987, 2005). A key factor determining the actual species composition is that according to current understanding of the species' habitat requirements over much of its range, the dice snake remains in the immediate vicinity of surface waters at a distance of less than 20 metres to the water edge during the active season (Conelli et al. 2011; Neumann and Mebert 2011; Velenský et al. 2011). As a result, the dice snake nearly exclusively feeds on aquatic and/or water-bound animals. The most important prey organisms are fish, especially in the European part of its distribution area, where over 75 species were recorded in the diet and $85 \%$ to $100 \%$

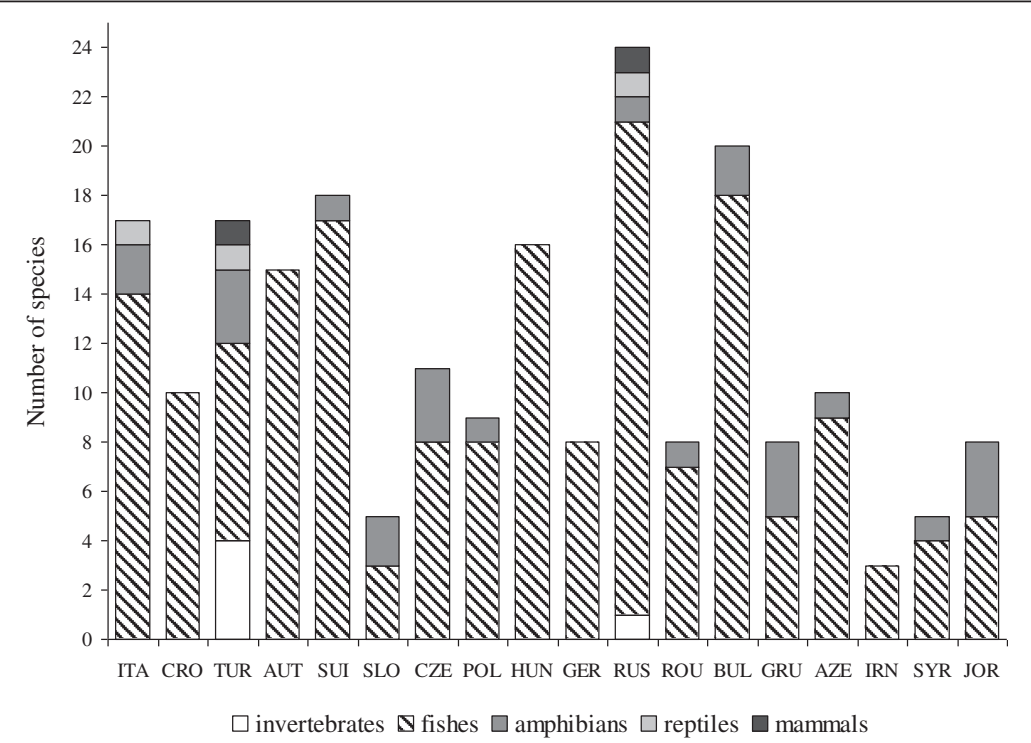

Figure 3 Geographical distribution of prey in the diet of Natrix tessellata. Invertebrates were united into one group due to their low number and similar distribution. Country codes: ITA: Italy, CRO: Croatia, TUR: Turkey, AUT: Austria, SUI: Switzerland, SLO: Slovenia, CZE: Czech Republic, POL: Poland, HUN: Hungary, GER: Germany, RUS: Russia, ROU: Romania, BUL: Bulgaria, GRU: Georgia, AZE: Azerbaijan, IRN: Iran, SYR: Syria, JOR: Jordan. 


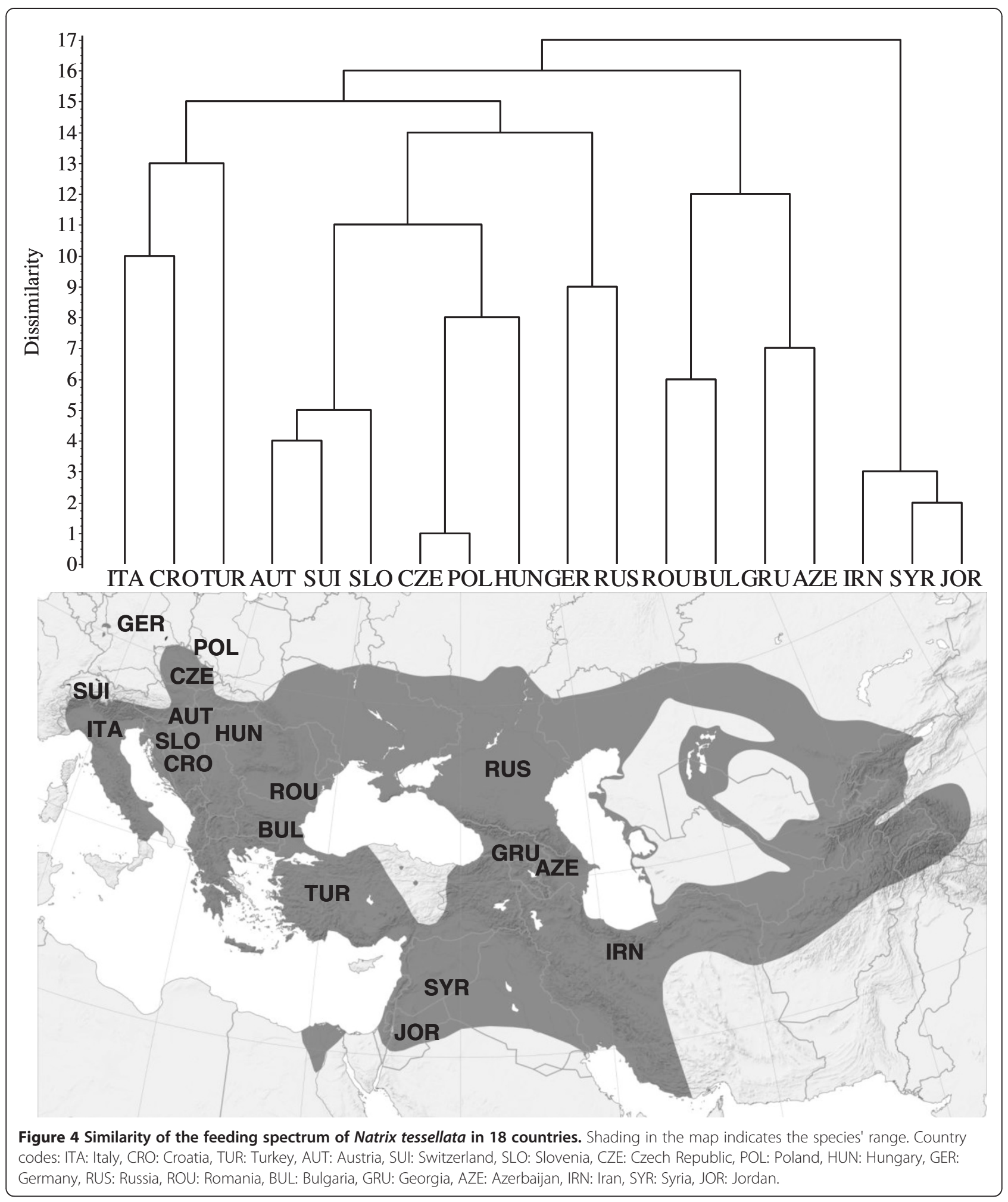

of food items belonged to this group. There is a clear relationship between fish species preyed upon and the size of water bodies. In seas, the dice snake may cover long distances up to several kilometres to hunt on benthic (Neogobius sp., Parablennius sp., Ponticola sp.) or open water marine (Clupeonella sp., Symphodus sp.,) fish species as it has been observed in the Caspian Sea (Tuniyev et al. 2011). In large lakes such as Lake Baćina (Hutinec and Mebert 2011), Lake Balaton (own unpublished data), Lake Prespa (Sterijovski et al. 2011), Lake Sinoe (Sloboda et al. 
2010) and Lake Geneva (Metzger et al. 2011), the dice snake mostly eats benthic fish (Neogobius sp., Cottus gobio) and/or fish species hidden in aquatic vegetation stands (Cyprinidae sp., and e.g. Blennius fluviatilis, Lepomis gibbosus, Perca fluviatilis). In large rivers, densely vegetated water courses and lakes, they hunt fish (mainly Cyprinidae sp.), amphibian larvae and adults (mainly Pelophylax and Rana sp.) near the bank (Acipinar et al. 2006; Filippi et al. 1996; Gaebele et al. 2013; Luiselli et al. 2007; Vlček et al. 2010; Weiperth et al. 2014; Zimmerman and Fachbach 1996). In fishponds, the main prey species of the dice snake were juvenile fish from aquaculture and allochthonous fish species (Acipinar et al. 2006) with occasional predation on amphibians (tadpoles and froglets) such as in Jordanian fish ponds (Amr and Disi 1998) (Additional file 1). With decreasing waterbody size, the feeding spectrum of the dice snake considerably changes to include terrestrial species besides fish and amphibians common in the given area (Amr and Disi 1998, 2011; Bakiev et al. 2011; Göçmen et al. 2011; Luiselli et al. 2007; Žagar et al. 2011) (Additional file 1). Populations in high mountains (over 1,000 m a.s.l.) may specialise on eating larval and adult amphibians (Cafuta and Krofel 2007; Frotzler et al. 2011; Tuniyev et al. 2011; Žagar et al. 2011) as predominant food. It can also be considerable in arid regions, where the dice snake often lives along temporary water bodies or fish ponds, where only a limited number of fish species are present (Amr and Disi 2011; Amr et al. 2011; Göçmen et al. 2011; Laňka 1978; Gruschwitz et al. 1999; Shehab et al. 2011). As young fish produced in fish farms can become an important element in the diet of the dice snake besides natural conditions, human activity may also influence the spread and survival of this snake (Acipinar et al. 2006; Göçmen et al. 2011).

\section{Abundance of prey taxa in the diet of the dice snake}

Several publications include estimates on the frequency of different prey organisms of the dice snake, including estimates for various habitats. Wang et al. (1987, 2005), for example, investigated 200 individuals and listed fish as the main food item in large, reed covered water bodies, insects, tadpoles and adult amphibians in temporarily water-covered rice paddies and connecting canals among them, and fish, tadpoles, insects and rodents (primarily mice) along streams in other agricultural areas in north-eastern China.

From the summary of detailed quantitative studies at half the sites only fish species were found in the dice snake (Figure 2); this result is characteristic for the species inhabiting permanent streams and large water bodies or rivers in Austria, Croatia, Romania and northern Turkey (Acipinar et al. 2006; Hutinec and Mebert 2011; Sloboda et al. 2010; Zimmerman and Fachbach 1996). Contradictory results were found on prey selection. For example, in Styrean waters, there was no complete overlap between the abundance of the different species in fish communities and in the diet of the dice snake (Zimmerman and Fachbach 1996), while in the Danube Delta, the number of snake-caught gobiid species was reflective of the abundance of the respective species in bottom habitats (Sloboda et al. 2010). Though the feeding spectrum of the studies was wide, fish were also the most abundant prey species at the other sites including the Mediterranean (Bakiev et al. 2011; Filippi et al. 1996; Luiselli et al. 2007). In one case, however, other food items (insects, amphibians, reptiles and mammals) in total were more numerous than fish (Göçmen et al. 2011). Though the number of these studies is limited, they support the general conclusion that over much of its range, the dice snake primarily feeds on fish, while in arid areas (see also Frotzler et al. 2011) and, according to Cafuta and Krofel (2007), also in high mountains, its diet may shift towards amphibians and other prey items.

\section{Geographical differences in the feeding spectrum of the dice snake}

The feeding spectrum of the dice snake differs among different regions, the analysis of the results revealed four main groups (Figure 4). The group separated most from other branches includes Asian countries with dice snake populations in highly arid regions (Iran, Syria, Jordan). The list of prey species in these countries is short, with snakes predominantly feeding on fish and amphibians from permanent rivers and alien fish species kept in fish farms (Amr and Disi 2011; Amr et al. 2011; Shehab et al. 2011). Fish ponds also function as refugia over the driest periods but at the same time the dice snake is under great predation pressure there due to the large number of aquatic birds present (Amr and Disi 2011; Bakaloudis et al. 1998; Shehab et al. 2011).

The second group in the cluster includes countries with the highest number of Ponto-Caspian gobiid species (e.g. Neogobius, Parablennius, Ponticola). Marine fish species are also common and amphibian predation was recorded in all countries of the Romanian-BulgarianGeorgian-Azerbaijani branch (Additional file 1) as well (Fautz 1986; Schülter 2006; Sloboda et al. 2010; Tuniyev et al. 2011).

Central and Eastern European countries formed a common group with Russia. There are several fish with very large distribution areas among the prey species there such as Alburnus alburnus, Squalius cephalus, Rutilus rutilus, Cyprinus carpio, Gobio gobio, Perca fluviatilis (Additional file 1). The Czech - Polish branch include countries with limited amphibian consumption (Rehak 1992; Švab 2003; Vlček et al. 2010), while high mountain populations (Austria, Switzerland, Slovenia) feeding on locally characteristic fish species and also on amphibians are on another sub-branch. 
Countries with Mediterranean climate (Croatia, Italy, Turkey) form the final group with freshwater tolerating marine fish species and cosmopolitan fish species in the diet of the dice snake. This area is characterised with the most diverse feeding spectrum including snails, insects, reptiles and mammals (Additional file 1, Figure 3) related to the drying out of many water bodies during summer. During extremely hot summers, the dice snake was also observed to hunt at night, also far away from surface waters, which furthers the potential feeding spectrum of this snake (see e.g. Moller 1990, who observed over a period of several weeks a large dice snake which 'unusually' hunted geckos at night).

Snakes have strikingly different feeding spectra ranging from strictly egg-eating species with limited distribution (see e.g. Dandge 2008) to generalist species living over large areas (Gregory and Isaac 2004). The dice snake is present in over 20 countries on three continents, which is, unlike what has been suggested earlier on the basis of observations from the western-central part of its distribution area, partly the result of its generalist feeding strategy leading to a good adaptive ability if the potential prey spectrum changes (Acipinar et al. 2006; Reshetnikov et al. 2013). It is also supported by its anatomy enabling this snake to hunt effectively in both aquatic and terrestrial environments (Bilcke et al. 2006, 2007; Brecko et al. 2011; Ghira et al. 2009; Wassenbergh et al. 2010). As such, a wide feeding spectrum had been expected as a result of this study. On the one hand, the global comparison supported the assumption that the dice snake is a piscivorous snake; it stressed the importance of fish in the diet. On the other hand, it revealed the complexity of the feeding spectrum including invertebrates, amphibians, reptiles and mammals and good adaptability to the effect of climate, altitude and even human activity, which explains why this species could colonise a large and diverse Eurasian range. Also, it elucidated the ability of this snake to survive under suboptimal conditions at the edge of its distribution, enter atypical habitats in natural areas such as high mountains as well as in human-dominated landscapes, such as rice paddies by shifting its diet even towards terrestrial or marine prey species.

Abiotic environmental parameters are known to have an important, but limited power in determining reptile distributions on a larger scale; other factors such as resources are also important (Guisan and Hofer 2003). As far as feeding spectra are concerned, the dice snake was considered to be in an intermediate position among the three Natrix species inhabiting the Palearctic. In a comparative study with the closely related grass snake (Natrix natrix), Luiselli and Rugiero (1991) found the dice snake to have a narrower feeding spectrum than the grass snake, which also has a broader distribution (Gasc et al. 1997). The latter species more plastically changing its diet and populations near to each other within relatively short distances may specialise on different food (Luiselli et al. 2005). What is more, the presence of the dice snake did not have any apparent effect on the food types eaten by grass snakes because grass snakes consumed fish when sympatric with $N$. tessellata (Luiselli et al. 2005). The diet of the third species, the viperine snake, Natrix maura, shows a considerable overlap with that of the dice snake but with some exceptions (see e.g. the observations of Scali, 2011), and due to other factors as fertility and size, the dice snake is able to outcompete the viperine snake (Metzger et al. 2011).

\section{Conclusions}

This study altered the hypothesis that the diet of the dice snake consists of fish from freshwater habitats as indicated by several authors. While this is still the majority of the diet, the feeding spectrum characteristically changed over the broad distribution of the species including non-fish prey as well as taxa from marine and terrestrial habitats as well. The dice snake is rather opportunistic in preying on fish, in total it was proved to eat at least 87 fish taxa, but it also takes other prey, primarily amphibians, when fishes are regionally not constantly available. The analysis of the feeding spectrum separated four large geographical units with further distinctions in Central and Eastern Europe. Such diversity helps explain why this species was able to colonise a large and diverse Eurasian range.

\section{Additional file}

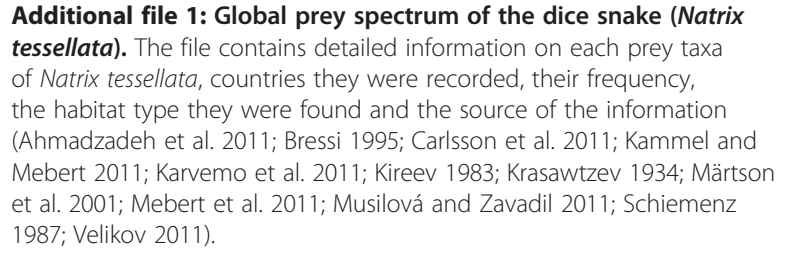

Additional file 1: Global prey spectrum of the dice snake (Natrix tessellata). The file contains detailed information on each prey taxa of Natrix tessellata, countries they were recorded, their frequency, the habitat type they were found and the source of the information (Ahmadzadeh et al. 2011; Bressi 1995; Carlsson et al. 2011; Kammel and Mebert 2011; Karvemo et al. 2011; Kireev 1983; Krasawtzev 1934; Märtson et al. 2001; Mebert et al. 2011; Musilová and Zavadil 2011; Schiemenz 1987; Velikov 2011).

Competing interests

The authors declare that they have no competing interests.

\section{Authors' contributions}

WA, GT, PI and PM participated in field sampling and overviewed the online databases, WA, PI and PM designed and prepared the additional file and processed the multi-lingual literature, WA and GT prepared the cluster analysis of country-based data presented in Figure 4, and PM finalized the manuscript with WA. All authors read and approved the final manuscript.

\section{Acknowledgements}

The authors thank Andrew Hamer and the anonymous reviewers for improving an earlier version of the manuscript.

\section{Author details}

${ }^{1}$ MTA Centre for Ecological Research, Danube Research Institute, Karolina út 29, Budapest 1113, Hungary. ${ }^{2}$ Szent István University, Faculty of Veterinary Science, István u. 2, Budapest 1078, Hungary. 
Received: 29 January 2014 Accepted: 4 July 2014

\section{Published: 23 July 2014}

\section{References}

Acipinar H, Gaygusuz O, Tarkan AS, Gürsoy CAZ (2006) Presence of an invasive fish species, Carassius gibelio (Bloch, 1782) in the diet of dice snake, Natrix tessellata (Laurenti, 1768). J Fish Aquat Sci 1(2):213-217

Ahmadzadeh F, Konrad M, Saeedeh A, Elham R, Goli LA, Böhme W (2011) Ecological and biological comparison of three populations of dice snakes (Natrix tessellata) from the southern Caspian Sea coast, Iran. Mertensiella 18:403-413

Amr ZS, Disi AM (1998) Diet of some snakes from Jordan. Amphibia-Reptilia 19:436-439

Amr ZS, Disi AM (2011) Systematics, distribution and ecology of the snakes of Jordan. Vertebr Zool 61(2):179-266

Amr ZS, Mebert K, Hamidan N, Baker MA, Disi A (2011) Ecology and conservation of the dice snake (Natrix tessellata) in Jordan. Mertensiella 18:393-400

Bakaloudis DE, Vlachost CG, Holloway GJ (1998) Habitat use by short-toed eagles Circaetus gallicus and their reptilian prey during the breeding season in Dadia Forest (north-eastern Greece). J Appl Ecol 35:821-828

Bakiev A, Kirillov AA, Mebert K (2011) Diet and parasitic helminths of dice snakes from the Volga Basin, Russia. Mertensiella 18:325-329

Bern Convention (1999) Law on ratification of convention of conservation of free living European flora and fauna and their natural habitats (Ur. I. RS 17/99).

Beshkov VA, Dushkov DT (1981) Materials on the batrachophagy and herpetophagy of snakes in Bulgaria. Ekologyia (Sofia) 9:43-50

Bilcke J, Herrel A, Damme RV (2006) Correlated evolution of aquatic prey-capture strategies in European and American natricine snakes. Biol J Linn Soc 88:73-83

Bilcke J, Herrel A, Aerts P (2007) Effect of prey- and predator size on the capture success of an aquatic snake. Belgian J Zool 137(2):191-195

Brecko J, Herrel A, Damme RV (2011) The relationships between head morphology and diet in the dice snake (Natrix tessellata). Mertensiella 18:20-29

Bressi N (1995) Erpetofauna delle foci del Fiume Isonzo, e note eco-etologiche sull'erpetofauna dell' isola della Cona (Friuli-Venezia Giulia, Italia Nordorientale). Atti Mus Civ Stor Nat Trieste 46:179-229

Cafuta V, Krofel M, (2007) Report on field work of the group for reptiles. In: Stanković, et al. (ed) Biology student research camp Lovrenc na Pohorju, (2005) Biology Student Society. Ljubljana, pp 81-88

Carlsson M, Karvemo S, Tudor M, Sloboda M, Mihalca AD, Ghira I, Bel L, Modry D (2011) Monitoring a large population of dice snakes at Lake Sinoe in Dobrogea, Romania. Mertensiella 18:237-244

Conelli AE, Nembrini M, Mebert K (2011) Different habitat use of dice snakes, Natrix tessellata, among three populations in Canton Ticino, Switzerland - a radiotelemetry study. Mertensiella 18:100-106

Dandge PH (2008) Food and feeding habits of Elachistodon westermanni Reinhardt, 1863. Hamadryad 32(1):86-88

European Union (1992) Council Directive 92/43/EEC of 21. May 1992 on the Conservation of Natural Habitats and of Wild Fauna and Flora (the Habitats Directive).

Fautz R (1986) The flounder, Platichthys flesus, as prey of the dice snake, Natrix tessellata, in Turkey. Zool Middle East 1:118-119

Filippi E, Capula M, Luiselli L, Agrimi U (1996) The prey spectrum of Natrix natrix (Linnaeus, 1758) and Natrix tessellata (Laurenti, 1768) in sympatric populations. Herpetozoa 8(3/4):155-164

Frotzler N, Davitashvili N, Mebert K (2011) Distribution of the dice snake (Natrix tessellata) in Georgia (Transcaucasia) and comparative notes on the genus Natrix. Mertensiella 18:357-364

Gaebele T, Potyó I, Weiperth A, Guti G, Puky M (2013) Abundant prey or optimal microhabitat? Natrix tessellata stays hidden in safe areas in a diverse floodplain along the Danube at Göd, Hungary. North-Western J Zool 9 (2):374-382

Gasc JP, Cabela A, Crnobrnja-Isailović J, Dolmen D, Grossenbacher K, Haffner P, Lescure J, Martens H, Martínez-Rica JP, Maurin H, Oliveira ME, Sofianidou TS, Veith M, Zuiderwijk A (eds) (1997) Atlas of Amphibians and Reptiles in Europe. Collection Patrimoines Naturels 29. Societas Europaea Herpetologica, Muséum National d'Histoire Naturelle \& Service du Patrimoine Naturel. Paris, France

Gautschi B, Widmer A, Joshi J, Koella JC (2002) Increased frequency of scale anomalies and loss of genetic variation in serially bottlenecked populations of the dice snake, Natrix tessellata. Conserv Genet 3(3):235-245
Ghira I, Butănescu D, Marosi B (2009) Feeding behavior of the dice snake (Natrix tessellata). Herpetologica Romanica 3:1-7

Göçmen B, Çiçek K, Yildiz MZ, Atatur MK, Dinçaslan YE, Mebert K (2011) A preliminary study on the feeding biology of the dice snake, Natrix tessellata, in Turkey. Mertensiella 18:365-369

Goodall DW (1953) Objective methods for the classification of vegetation I. The use of positive interspecific correlation. Aust J Bot 1:39-63

Gregory PT, Isaac LA (2004) Food habits of the grass snake in southeastern England: is Natrix natrix a generalist predator? J Herpetol 38(1):88-95

Gruschwitz M, Lenz S, Mebert K, Laňka V (1999) Natrix tessellata (Laurenti, 1768) Wurfelnatter. In: Bohme W (ed) Handbuch der Reptilien und Amphibien Europas. Bd. 3/Schlangen II, AULA-Verlag, Wiesbaden, Germany, pp 581-644

Guicking D, Herzberg A, Wink M (2004) Population genetics of the dice snake (Natrix tessellata) in Germany: implications for conservation. Salamandra 40(43/4):217-234

Guisan A, Hofer U (2003) Predicting reptile distributions at the mesoscale: relation to climate and topography. Journal of Biogeography 30:1233-1243

Hutinec JB, Mebert K (2011) Ecological partitioning between dice snakes (Natrix tessellata) and grass snakes (Natrix natrix) in southern Croatia. Mertensiella 18:225-233

Ibrahim AA (2012) New records of the dice snake, Natrix tessellata, in the Suez Canal zone and Sinai. Amphibian Reptile Conservation 6(2):2-4

IUCN (2012) IUCN Red list of threatened species. Version 2012.2, www.iucnredlist. org. Accessed 27/11/2013

Kammel W, Mebert K (2011) Effects of rehabilitation of the polluted river system Mur in Styria, Austria, and construction of hydroelectric power plants on fish fauna and distribution of the dice snake. Mertensiella 18:188-195

Karvemo S, Carlsson M, Tudor M, Sloboda M, Mihalca AD, Ghiram I, Bel L, Modry D (2011) Gender differences in seasonal movement of dice snakes in Histria, southeastern Romania. Mertensiella 18:245-254

Khonjakina ZP (1969) Materialy po rasprostraneniju i biologii vodjanogo uzha $\checkmark$ Dagestane. Spornik nauchnykh soobscheniy kaf. zool. DGU C6, Makhachkala, pp 82-84

Kireev VA (1983) Fauna of Kalmykia - amphibians and reptiles. Kalmykia Publisher, Elista, Russia

Krasawtzev BA (221) O pitanii nekotorykh zmej v Dagestane. Izv. 1 i 2 Severo Kavkazskogo Ped, Instituta. Bd. 2/P, Ordzhonikidze, p 222

Kreiner G (2007) The snakes of Europe: all species from west of the Caucasus Mountains. Frankfurt am Main, Edition Chimaria

Lahav S, Dmi'el R (1996) Skin resistance to water loss in colubrid snakes: ecological and taxonomical correlations. Ecoscience 3(2):135-139

Laňka V (1978) Variabilitat und Biologie der Würfelnatter (Natrix tessellata). Acta Universitatis Carol Biol 1975-1976:167-207

Luiselli L, Rugiero L (1991) Food niche partitioning by water snakes (Genus Natrix) at a freshwater environment in Central Italy. Journal of Freshwater Ecology 6(4):439-444

Luiselli L, Filippi E, Capulla M (2005) Geographical variation in diet composition of the grass snake (Natrix natrix) along the mainland and an island in Italy: the effect of habitat type and interference with potential competitors. The Herpetological Journal 15(4):221-230

Luiselli L, Capizzi D, Filippi E, Anibaldi C, Rugiero L, Capula M (2007) Comparative diets of three populations of an aquatic snake (Natrix tessellata, Colubridae) from Mediterranean streams with different hydric regimes. Copeia 2:426-435, doi:10.1643/0045-8511(2007)7[426:CDOTPO]2.0.CO;2

Märtson M, Taittonen M, Alanen M, Reunanen M (2001) Vipera berus adder bite in the water, complicated by rapid shock. A case history. Eur J Pediatr Surg 5:358-360

Mebert K, Conelli AE, Nembrini M, Schmidt BR (2011) Monitoring and assessment of the distribution of the dice snake in Ticino, southern Switzerland. Mertensiella 18:117-130

Mebert K, Masroor R, Chaudhry MJI (2013) The dice snake, Natrix tessellata (Serpentes: Colubridae) in Pakistan: analysis of its range limited to few valleys in the Western Karakoram. Pakistan J Zool 45(2):395-410

Metzger C, Christe P, Ursenbacher S (2011) Diet variability of two convergent natricine colubrids in an invasive-native interaction. Mertensiella 18:86-93

Moller T (1990) Zur Herpetofauna im Suden Bulgariens. Aquar Terrar Zeitschrift Stuttgart 43(7):431-434

Musilová R, Zavadil V (2011) Užovka podplamatá v České republice. Zoo Rep Mag Pro Prátala Zoo Brno 1:1-4

Nekrasova OD, Gavris GG, Kuybida W (2013) Changes in the northern border of the home range of the dice snake, Natrix tessellata (Reptilia, Comunridae), in the Dnipro Basin (Ukraine). Vestnik Zool 47(5):67-71 
Podani J (2001) SYN-TAX 2000. Computer program for data analysis in ecology and systematics. Scientia Kiadó, Budapest

Radovanović M (1951) Vodozemci i gmizavci naše zemlje. Naučna Knjiga, Beograd, Serbia

Rehak I (1992) Natrix tessellata (Laurenti, 1768). Baruš V, Oliva O (eds) Užovka podplamata, Fauna ČSFR. Plazi-Reptilia svazek 26, Academia, Praha, pp 125-134

Reshetnikov AN, Sokolov SG, Chikhlyaev IV, Fayzulin Al, Kirillov AA, Kuzovenko AK, Protasova EN, Skomorokhov MO (2013) Direct and indirect interactions between an invasive alien fish (Perccottus glenii) and two native semi-aquatic snakes. Copeia 2013(1):103-110. doi:10.1643/CE-12-007

Scali S (2011) Ecological comparison of the dice snake (Natrix tessellata) and the viperine snake (Natrix maura) in Northern Italy. Mertensiella 18:131-144

Schiemenz H (1987) Die Kreuzotter. Die Neue Brehm Bucherei. A, Ziemens Verlag, Wittenberg, Lutherstadt, Germany

Schülter U (2006) Die Herpetofauna der bulgarischen Schwarzmeerküste - Teil 3: Schlangen. Elaphe 14(2):59-66

Shehab AH, Masri AA, Zuhair S, Amr ZS (2011) The dice snake (Natrix tessellata) in Syria: distribution, trade and conservation. Mertensiella 18:388-392

Sloboda M, Mihalca AD, Falka I, Petrželková KJ, Carlsson M, Ghira I, Modry D (2010) Are gobiid fish more susceptible to predation if parasitized by Eustrongylides excisus? An answer from robbed snakes. Ecol Restor 25:469-473

Sterijovski B, Ajtić R, Tomović L, Djordjević S, Djurakić M, Golubović A, Isailović CJ, Ballouard JM, Desmont D, Groumpf F, Bonnet X (2011) Natrix tessellata on Golem Grad, FYR of Macedonia: a natural fortress shelters a prosperous snake population. Mertensiella 18:298-301

Švab M (2003) Ekologie Užovky Podplamate (Natrix tessellata) ve Střednich Čechach. Zoologie, Praha, Czech Republic, M.S. Kat

Tuniyev B, Tuniyev S, Kirschey T, Mebert K (2011) Notes on the dice snake, Natrix tessellata, from the Caucasian Isthmus. Mertensiella 18:343-356

Velenský M, Velenský P, Mebert K (2011) Ecology and ethology of dice snakes (Natrix tessellata) in the city district Troja, Prague. Mertensiella 18:157-175

Velikov I (2011) Dice snake feeds on spiny invasive fish. Mertensiella 18:447

Vignoli L, Mocaer I, Luiselli L, Bologna MA (2009) Can a large metropolis sustain complex herpetofauna communities? An analysis of the suitability of green space fragments in Rome. Anim Conserv 12:456-466

Vlček P, Najbar B, Jablonski D (2010) First records of the dice snake (Natrix tessellata) from the North-Eastern part of the Czech Republic and Poland. Herpetology Notes 3:23-26

Wang G, Qi W, Ma M, Wang H, Lei J (1987) Population ecology of Natrix tessellata (Laurenti, 1768) (in Chinese). Arid Zone Res 28(2):35-40

Wang G, Fan Y, Zhai RX (2005) Distribution and ecology of snakes in Xinjiang (in Chinese). Arid Zone Res 22(2):181-185

Wassenbergh SW, Brecko J, Aerts P, Stouten I, Vanheusden G, Camps A, Damme RV, Herrel A (2010) Hydrodynamic constraints on prey-capture performance in forward-striking snakes. J R Soc Interface 2010(7):773-785. doi:10.1098/ rsif.2009.0385

Weiperth A, Potyó I, Puky M (2014) Diet composition of the dice snake (Natrix tessellata Laurenti, 1768) (Reptilia: Columbridae) in the Danube River Catchment area. Acta Zool Bulg Suppl 7:51-56

Williams WL, Lambert JM (1960) Multivariate methods in plant ecology. I Association analysis in plant community J Ecol 47:83-101

Žagar A, Krofel M, Govedič M, Mebert K (2011) Distribution and habitat use of dice snakes, Natrix tessellata, in Slovenia. Mertensiella 18:193-202

Zimmerman P, Fachbach G (1996) Verbreitung und Biologie der Würfelnatter Natrix tessellata tessellata (Laurenti, 1768), in der Steiermark (Österreich). Herpetozoa 8(3/4):99-124

\section{doi:10.1186/s40555-014-0042-2}

Cite this article as: Weiperth et al:: A global overview on the diet of the dice snake (Natrix tessellata) from a geographical perspective: foraging in atypical habitats and feeding spectrum widening helps colonisation and survival under suboptimal conditions for a piscivorous snake. Zoological Studies 2014 53:42.

\section{Submit your manuscript to a SpringerOpen ${ }^{\odot}$ journal and benefit from:}

- Convenient online submission

$\checkmark$ Rigorous peer review

- Immediate publication on acceptance

- Open access: articles freely available online

- High visibility within the field

- Retaining the copyright to your article

Submit your next manuscript at $>$ springeropen.com 